\title{
PENGARUH LIKUIDITAS, EFEKTIVITAS AKTIVA DAN UKURAN PERUSAHAAN TERHADAP KEBIJAKAN DIVIDEN DAN HARGA SAHAM \\ Oleh
}

Lutvi Alamsyah, SE, MM

E-mail lutvitjia5@gmail.com

\begin{abstract}
The dividends distributed by the company depend on the policies adopted by the company about the distribution of dividends. Dividend distribution was predicted to affect the movement of stock prices in the market. Manufacturing company consisting of various types of companies are very apt to be sampled in order to examine the factors that affect dividend policy and stock price. Ten manufacturing companies into the sample through purposive sampling with sampling data sources used in this study is secondary data. Hypothesis testing is done with path analysis with multiple regression models as an intervening variable dividend policy.
\end{abstract}

Keywords: Dividend policy and stock prices

\section{PENDAHULUAN}

\section{Latar belakang}

Kebijakan dividen adalah keputusan apakah laba yang diperoleh perusahaan akan dibagikan kepada pemegang saham sebagai dividen atau akan ditahan dalam bentuk laba ditahan guna pembiayaan investasi di masa datang. Apabila perusahaan memilih untuk membagikan laba sebagai dividen, maka akan mengurangi laba yang ditahan dan selanjutnya mengurangi total sumber dana intern atau keuangan internal. Sebaliknya jika perusahaan memilih untuk menahan laba yang diperoleh, maka kemampuan pembentukan dana intern akan semakin besar. Dengan demikian kebijakan dividen ini harus dianalisa .

Kebijakan dividen merupakan kunci return yang didapatkan investor berupa dividen. Menilai baik buruknya kinerja perusahaan sering terlihat pada kebijakan dividennya (Khan et al., 2011). Keputusan penentuan jumlah persebaran laba ditahan dengan besar dividen yang dibagikan ialah ciri khas kebijakan dividen (Purwanti,2010). Kebijakan dividen seringkali dihadapkan pada dua pihak yang berkepentingan dengan tujuan yang berlawanan. Dividen kas dipengaruhi beragam faktor terutama keterkaitan komponen yang ada pada laporan keuangan. Pengembalian utama dalam penentuan nilai perusahaan didasari oleh dividen kas (Martati, 2010). Harga saham merupakan cerminan kepuasan serta kekecewaan investor akan dividen. Menurut Sartono (2010:289) dalam teori information content of hypothesis menyatakan bahwa pergerakan harga saham yang ada mengikuti jumlah dividen yang dibagikan. Harga saham dipengaruhi secara positif oleh kebijakan 
dividen (Ashgar et al., 2011). Farooq (2012), Hussainey et al. (2010) dan Hashemijoo et al. (2012) mengutarakan perbedaan pendapatnya dimana harga saham dipengaruhi secara negatif oleh kebijakan dividen. Ali and Chowdhury (2010) serta Rashid and Anisur (2007) beranggapan bahwa kebijakan suatu dividen yang ada berpengaruh tidak signifikan terhadap tingginya harga saham.

Moradi et al. (2012) mengungkapkan sejumlah faktor yang diprediksi dapat memengaruhi kebijakan dividen diantaranya likuiditas, aktivitas perusahaan dan ukuran perusahaan. Kondisi semakin likuid yang dimiliki suatu perusahaan akan memungkinkan dilakukannya pembagian dividen, permasalahan justru muncul saat posisi likuiditas terlalu tinggi ataupun sebaliknya (Arilaha, 2009).

Rasio aktivitas yang merupakan refleksi terhadap efisiensi dalam penggunaan dana juga memiliki bagian dalam pengaruhnya terhadap kebijakan dividen (Sumiadji, 2011). Perbedaan pengaruh justru dikemukakan oleh Fabrurozi (2007) dimana kebijakan dividen keberadaanya tidak dipengaruhi oleh efisiensi penggunaan dana. Ihsan (2009) menambahkan harga saham keberadaannya tidak dipengaruhi oleh penggunaan dana secara efisien berbeda dengan Ali dan Razi (2012) keadaan penggunaan dana dari penjualan sangat memengaruhi harga saham.

Ukuran perusahaan berkaitan besar pengaruhnya dengan kemampuan dividen dibagikan (Juma'ah et al., 2007) sehingga aspek tersebut membawa isu pada gerak harga saham di pasar (Sharma, 2011). Sektor manufaktur memerlukan modal dasar aset yang besar seperti adanya penyusutan dibandingkan dengan sektor jasa ataupun yang lainnya sehingga akan berpengaruh terhadap dividen tunai yang akan dibagikan (Gill et al., 2010). Industri manufaktur di Bursa Efek Indonesia kurun waktu 20082011 dilakukan dalam penelitian ini.

\section{METODE PENELITIAN}

Data yang didapatkan berupa data kuantitatif dimana jenis data yang berbentuk angka (Sugiyono, 2008:13) yang digunakan dalam penelitian ini. Penelitian ini bersumber data sekunder yaitu menurut Dewanti dan Sudiartha (2010) merupakan data dalam bentuk jadi yang telah dikumpulkan. Purposive sampling merupakan teknik penentuan sampel keterkaitan kebijakan dividen terhadap harga saham yang digunakan dengan pemecahan masalah pengaruh variabel eksogen terhadap variabel endogen menggunakan analisis path.

Variabel endogen di dalam penelitian ini ialah harga saham dengan indikator harga saham saat penutupan. Variabel intervening berupa kebijakan dividen diukur dengan indikator dividen per share serta variabel eksogen yang memengaruhinya yaitu likuditas, efektivitas aktiva dan ukuran perusahaan. 


\section{HASIL PENELITIAN DAN PEMBAHASAN}

\section{Uji Asumsi Klasik}

Uji normalitas pada Tabel 1 menunjukkan model pertama berdistribusi normal dengan taraf signifikansi sebesar 0,473 dan tabel 2 merupakan hasil output spss model kedua menunjukkan data berdistribusi normal dimana taraf signifikansi sebesar 0,381. Nilai VIF < 10 menunjukkan data bebas akan gejala multikolinearitas. Hasil output SPSS pada Tabel 3 untuk model pertama dan Tabel 4 untuk model kedua menunjukkan nilai VIF < 10, sehingga penelitian ini bebas dari gejala multikolineritas.

Nilai Durbin-Watson yang didapat pada model pertama adalah sebesar 1,730 dan pada model kedua adalah 1,820 dan tidak menunjukkan autokorelasi adalah lebih kecil dari 4-Du dan lebih besar dari DU. Nilai DW model pertama ialah 1,730 dan model kedua ialah 1,820 sesuai dengan kriteria lulus uji autokorelasi, maka autokorelasi tidak terdapat pada keseluruhan data yang dibuat.

Hasil uji signifikansi di atas 0,05 menunjukkan data tidak mengandung gejala heteroskedastisitas dimana output untuk model pertama pada Tabel 7 dan model kedua pada Tabel 8 menunjukkan bahwa uji signifikansi di atas 0,05, sehingga bebas dari gejala heteroskedastisitas.

\section{HASIL PENGUJIAN HIPOTESIS}

\section{Likuiditas Berpengaruh Tidak Signifikan terhadap Kebijakan Dividen dan}

\section{Berpengaruh Negatif Signifikan terhadap Harga Saham}

Tabel 9 menunjukkan kebijakan dividen yang dipengaruhi likuiditas ternyata berpengaruh tidak signifikan. Penelitian Satmoko dan Ediningsih (2009) dan Yiadom dan Samuel (2011) serupa, tetapi bertentangan pengajuan hipotesis yaitu kebijakan dividen dipengaruhi likuditas secara positif signifikan.

Tabel 10 menunjukkan harga saham dipengaruhi oleh likuiditas secara negatif signifikan. Malintan (2010) memaparkan kemampuan output yang tidak maksimal disebabkan oleh kepemilikan kas yang menganggur, tetapi bertentangan dengan hipotesis yang diajukan yaitu likuiditas berpengaruh positif signifikan terhadap harga saham.

\section{Efektivitas Aktiva Berpengaruh Tidak Signifikan terhadap Kebijakan Dividen}

\section{dan Berpengaruh Tidak Signifikan terhadap Harga Saham}

Tabel 9 menunjukkan kebijakan dividen yang dipengaruhi efektivitas aktiva ternyata berpengaruh tidak signifikan. Hasil penelitian ini sejalan dengan penelitian 
Deitiana (2009), akan tetapi bertentangan dengan hipotesis yang diajukan yaitu efektivitas aktiva berpengaruh positif signifikan terhadap kebijakan dividen.

Tabel 10 menunjukkan harga saham yang dipengaruhi efektivitas aktiva ternyata berpengaruh tidak signifikan. Hasil penelitian ini sejalan dengan penelitian Subalno (2009), akan tetapi bertentangan dengan pengajuan hipotesis yaitu harga saham dipengaruhi secara positif signifikan oleh efektivitas aktiva (Deitiana, 2011).

\section{Ukuran Perusahaan Berpengaruh Positif Signifikan terhadap Kebijakan \\ Dividen dan Berpengaruh Negatif Signifikan Terhadap Harga Saham}

Tabel 9 menunjukkan kebijakan dividen yang dipengaruhi ukuran perusahaan ternyata berpengaruh positif signifikan. Hasil penelitian ini sejalan dengan penelitian Imran (2011) dan hipotesis yang diajukan dapat diterima.

Tabel 10 menunjukkan harga saham yang dipengaruhi ukuran perusahaan ternyata negatif tidak signifikan. Pengaruh positif signifikan ukuran perusahaan terhadap harga saham sebagai hipotesis ditolak. Hasil penelitian ini sejalan dengan hasil penelitian Hashemijoo et al. (2012) semakin besar ukuran perusahaan dapat meningkatkan ketidakefisiensian operasi perusahaan dalam berproduksi dan berdampak pada ketidakoptimalan dalam menghasilkan laba. Investor yang melihat hal tersebut tidak akan tertarik untuk menanamkan sahamnya dan harga saham akan menurun.

\section{Kebijakan Dividen Berpengaruh Positif Signifikan terhadap Harga Saham}

Tabel 10 menunjukkan harga saham yang dipengaruhi ukuran perusahaan ternyata negatif tidak signifikan. Pengajuan hipotesis sesuai dengan hasil penelitian dan sejalan dengan hasil penelitian Adesola dan Okwong (2009).

\section{KELAYAKAN MODEL}

\section{Uji Signifikansi Simultan (Uji F)}

Taraf $\alpha$ nilai $\mathrm{F}$ hitung yang lebih kecil dari 0,05 menunjukkan uji signifikansi simultan dapat diterima. Uji simultan model pertama ialah 0,010 dan uji simultan model kedua ialah sebesar 0,000, sehingga secara serempak variabel eksogen model pertama dan kedua berpengaruh terhadap variabel endogen. 


\section{Koefisien Determinasi}

Koefisien determinasi penelitian ini menunjukkan sebesar 91,1\% model yang dibentuk mengandung informasi, sisanya variabel lain diluar model yang dibentuk menjelaskan sebesar $8,9 \%$.

\section{SIMPULAN}

Likuiditas dan efektivitas aktiva berpengaruh tidak signifikan terhadap kebijakan dividen, sedangkan ukuran perusahaan berpengaruh positif signifikan terhadap kebijakan dividen. Likuiditas serta ukuran perusahaan berpengaruh negatif signifikan terhadap harga saham, harga saham dipengaruhi efektivitas aktiva tidak signifikan dan kebijakan dividen berpengaruh terhadap harga saham secara positif signifikan pada perusahaan manufaktur yang terdaftar di Bursa Efek Indonesia periode 20082011.

\section{SARAN}

Saran bagi pihak manajemen perusahaan yang akan membagikan dividen, perlu mempertimbangkan kemampuan perusahaan jangka panjang dalam berinvestasi, sedangkan bagi investor perlu secara cermat dalam melihat faktor-faktor yang memengaruhi harga saham suatu perusahaan untuk berinvestasi.

\section{DAFTAR PUSTAKA}

Adesola, W. A., and A. E. Okwong. 2009. An Emperical Study of Dividend Policy of Quoted Companies in Nigeria. Global Journal of Social Sciences, 8 (1), pp: 85-101.

Ali, Mohammad Bayezid., and Tanbir Ahmed Chowdhury. 2010. Effect of Dividend on Stock Price in Emerging Stock Market: A Study on the Listed Private Commercial Banks in DSE. International Journal of Finance and Economics, 2 (4), pp: 52-64.

Ali, Syed Atif and Amir Razi. 2012. Impact of Companies Internal Variables on Stock Prices: A Case Study of Major Industries of Pakistan. International Conference on Education, Applied Sciences and Management, pp: 141-144.

Arilaha, Muhammad Asril. 2009. Pengaruh Free Cash Flow, Profitabilitas, Likuiditas, dan Leverage Terhadap Kebijakan Dividen. Jurnal Keuangan dan Perbankan, 13 (1), pp: 78-87. 
Ashgar, Muhammad., Syed Zulfiqar Ali Shah, Kashif Hamid, Muhammad Tahir Suleman. 2011. Impact of Dividend Policy on Stock Price Risk: Emperical Evidence from Equity Market of Pakistan. Far East Journal of Psycology and Business. 4 (1), pp: 45-52.s

Deitiana, Tita. 2009. Faktor-Faktor yang Mempengaruhi Kebijakan Pembayaran Dividen Kas. Jurnal Bisnis dan Akuntansi, 11 (1), pp: 57-64.

------. 2011. Pengaruh Rasio keuangan, Pertumbuhan Penjualan dan Dividen terhadap Harga Saham. Jurnal Bisnis dan Akuntansi, 13 (1), pp: 57-66.

Dewanti, Made Ayu Lisna., Gede Merta Sudiartha. 2010. Pengaruh Cash Ratio, Debt To Equity Ratio dan Earning Per Share terhadap Cash Dividend pada Perusahaan Food and Beverages yang terdaftar di Bursa Efek Indonesia Periode 2005-2010. Jurnal Fakultas Ekonomi Universitas Udayana, pp: 1-15.

Fabrurrozi. 2007. Analisis Faktor-Faktor yang Mempengaruhi Penentuan Kebijakan Pembagian Dividen pada Perusahaan Manufaktur di Bursa Efek Jakarta. Jurnal Tepak Manajerial Magister Manajemen, 7 (7), pp: 29-42.

Farooq, Omar. 2012. Dividend Policy as a Signaling Mechanism under Different Market Conditions: Evidence from Casablanca Stock Exchange. Internatioinal Research Journal of Finance and Economics, pp: 187-198.

Gill, Amarjit., Nahum Biger dan Rajendra Tibrewala. 2010. Determinants of Dividend Payout Ratios: Evidence From Unites State. The Open Business Journal, 3, pp: 8-14.

Hashemi, Seyed Abbas and Fatemeh Zahra Kashani Zadeh. 2012. The Impact of Financial Leverage Operating Cash Flow and Size of Company on Dividend Policy. Interdiciplinary Journal of Contemporary Research in Bussines, 3 (10), pp: 264-270.

Hashemijoo, Mohammad., Aref Mahdavi Ardekani and Nejat Younesi. 2012. The Impact of Dividend Policy on Share price Volatility in the Malaysian Stock Market. Journal of Bussines Studies Quarterly, 4 (1), pp: 111-129.

Hussainey, Khaled and Chijoke Oscar MGBAME. Dividend Policy and Share Price Volatility: UK Evidence. Journal of Risk Finance, pp: 1-21. 
Ihsan, Mohd. 2009. Pengaruh current ratio (CR), total assets turnover (TATO), debt to equity ratio (DER), dan return on investment (ROI) terhadap Harga Saham Industri Apparel di BEJ. Percikan, 96, pp: 1-7.

Imran, Kashif. 2011. Determinants of Dividend Payout Policy: A Case of Pakistan Engineering Sector. The Romanian Economic Journal, 14 (41), pp: 47-60.

Juma'ah, Ahmad H., Oliveras Pacheco and Carlos J. The Economic and Behavioral Determinants of Cash Dividend Policy. Forum Empresarial Journal, 12 (2), pp: 54-75.

Khan, Kanwal Iqbal., Muhammad Aamir, Arslan Qayyum, Adeel Nasir and Maryam Iqbal Khan. 2011. Can Dividend Decisions Affect the Stock Prices: A Case Of Dividend Paying Companies of CSE. International Research Journal of Finance and Economics, 76 (68), pp: 69-74.

Malintan, Rio. 2010. Pengaruh Current Ratio, Debt to Equity Ratio, Price Earning Ratio dan Return on Assets terhadap Return Saham Perusahaan Pertambangan yang Terdaftar di Bursa Efek Indonesia Tahun 2005-2005. Pp: 2-25.

Martati, Indah. 2010. Faktor Penentu Dividend Per Share Perusahaan Manufaktur yang Terdaftar pada Bursa Efek Indonesia. Jurnal EKSIS, 6 (2) pp: 1440-1605

Moradi, Javad., Hashem Valipour and Seyedeh Sara Mousavi. 2012. Determinants Factors of Dividend Policy in Firm Listed in Tehran Stock Exchange (TSE).

American Journal of Scientific Research, ISSN 1450-223 (45), pp: 22-32.

Rashid, Afzalur dan A. Z. M. Anisur Rahman. 2007. Dividend Policy and Stock Price Volatility: Evidence from Bangladesh. Journal of Applied Business and Economics, pp: 1-11.

Sartono, Agus. 2010. Manajemen Keuangan Teori dan Aplikasi. Edisi Empat. Yogyakarta: BPFE-Yogyakarta.

Satmoko, Agung dan Sri Isworo Ediningsih. 2009. Faktor-faktor yang Mempengaruhi Dividen Kas Perusahaan Manufaktur di Bursa Efek Indonesia. Pp: 1-18.

Sharma, Sanjeet. 2011. Determinants of Equity Share Prices in India. Journal of Arts, 
Science and Commerce, 2 (4), pp: 51-60.

Subalno. 2009. Analisis Pengaruh Faktor Fundamental dan Kondisi Ekonomi Terhadap Return Saham. Tesis Program Studi Manajemen Program Pasca Sarjana Universitas Diponegoro. Semarang.

Sugiyono. 2008. Metode Penelitian Bisnis. Alfabeta: Bandung.

Sumiadji. 2011. Analisis Variabel Keuangan yang Memengaruhi Kebijakan Dividen pada Perusahaan Manufaktur Periode 2004-2008. Jurnal Dinamika Akuntansi, 3 (2), pp: 129-138.

Yiadom, Edward Marfo and Samuel Kwaku Agyei. 2011. Determinants of Dividend Policy of Banks in Ghana. International Research Journal, ISSN 1450-2887 (61), pp: 99-108. 
Tabel 1 Uji Normalitas

Model Pertama

\begin{tabular}{|l|c|}
\hline & $\begin{array}{c}\text { Unst } \\
\text { Residual }\end{array}$ \\
\hline Asymp. Sig. (2-tailed) & 0,473 \\
\hline
\end{tabular}

Sumber: Output SPSS

Tabel 2 Uji Normalitas

Model Kedua

\begin{tabular}{|l|c|}
\hline & $\begin{array}{c}\text { Unst } \\
\text { Residual }\end{array}$ \\
\hline Asymp. Sig. (2-tailed) & 0,381 \\
\hline
\end{tabular}

Sumber: Output SPSS

Tabel 3 Uji Multikolinearitas

\section{Model Pertama}

\begin{tabular}{|l|r|c|}
\hline \multirow{2}{*}{ Model } & \multicolumn{2}{|c|}{ Collinearity Statistics } \\
\cline { 2 - 3 } & Tolerance & VIF \\
\hline CR & 0,701 & 1,426 \\
TATO & 0,833 & 1,201 \\
FZ & 0,603 & 1,658 \\
\hline
\end{tabular}

Sumber: Output SPSS

\section{Tabel 4 Uji Multikoliniearitas}

\section{Model Kedua}

\begin{tabular}{|l|r|c|}
\hline \multirow{2}{*}{ Model } & \multicolumn{2}{|c|}{ Collinearity Statistics } \\
\cline { 2 - 3 } & Tolerance & \multicolumn{1}{c|}{ VIF } \\
\hline CR & 0,666 & 1,502 \\
TATO & 0,826 & 1,211
\end{tabular}




\begin{tabular}{|l|l|r|} 
FZ & 0,452 & 2,212 \\
DPS & 0,732 & 1,366 \\
\hline
\end{tabular}

Sumber: Output SPSS

Tabel 5 Uji Autokorelasi

Model Pertama

\begin{tabular}{|l|r|}
\hline Model & Durbin Waston \\
\hline 1 & 1,730 \\
\hline
\end{tabular}

Sumber: Output SPSS

Tabel 6 Uji Autokorelasi

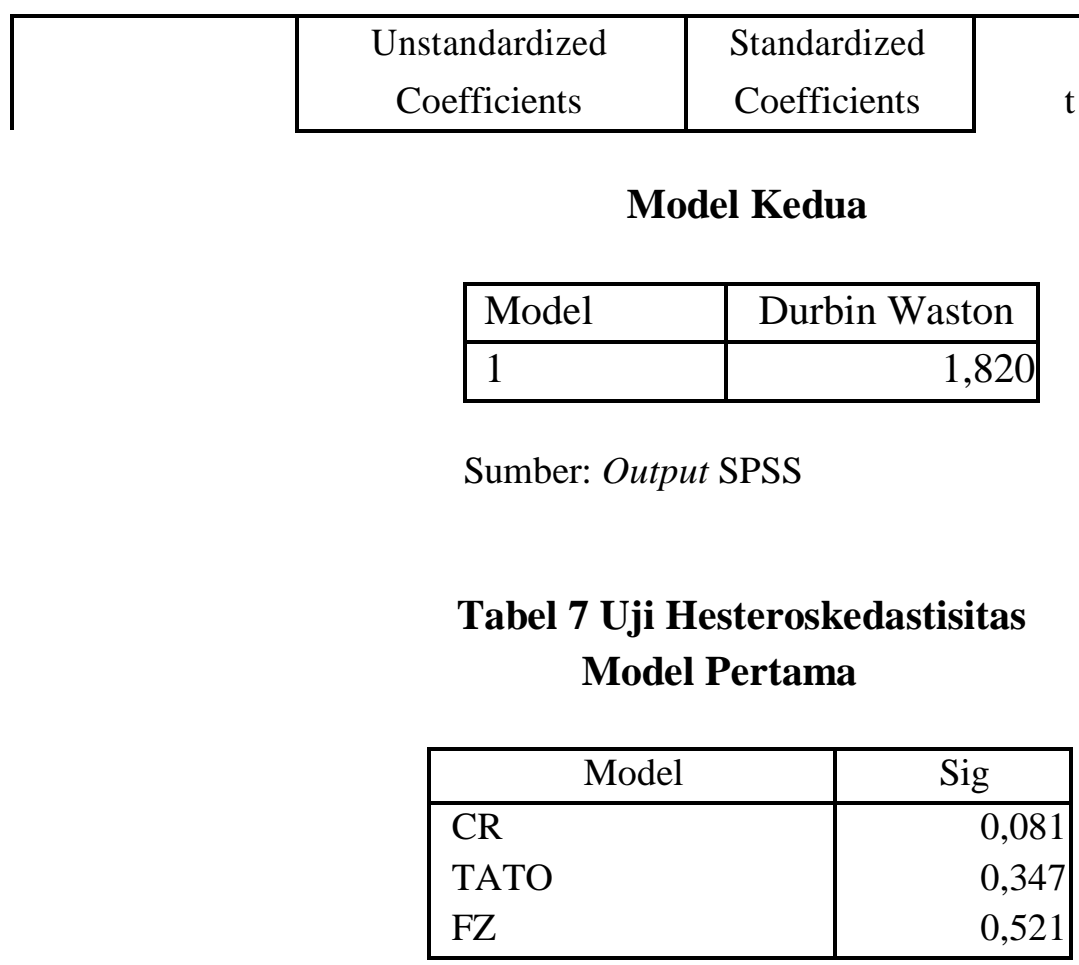

Sumber: Output SPSS

Tabel 8 Uji Hesteroskedastisitas

Model Kedua

\begin{tabular}{|l|r|}
\hline \multicolumn{1}{|c|}{ Model } & \multicolumn{1}{c|}{ Sig } \\
\hline CR & 0,226 \\
TATO & 0,338 \\
FZ & 0,925 \\
DPS & 0,084 \\
\hline
\end{tabular}

Sumber: Output SPSS 
Tabel 9 Rekapitulasi Output Pengaruh Langsung

Model Kedua

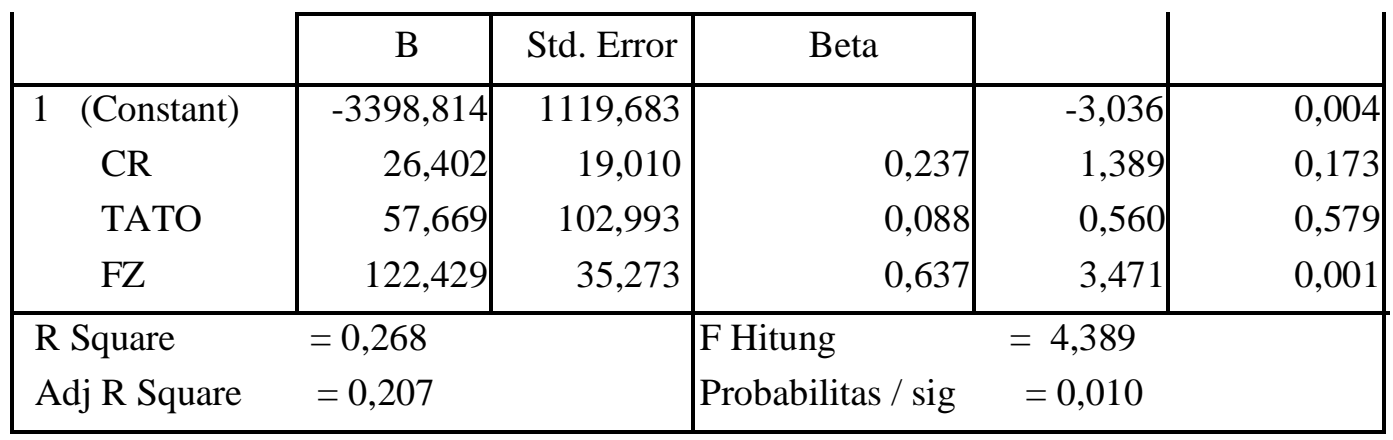

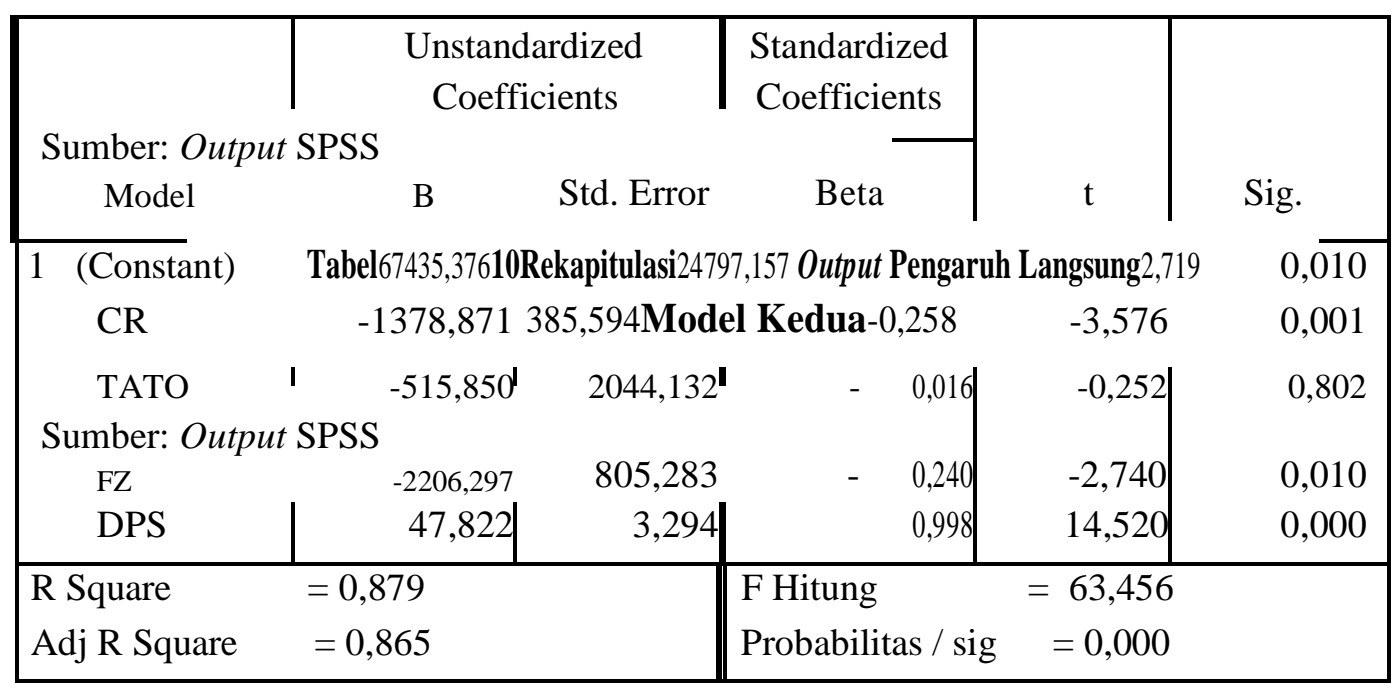

